\title{
Fatigue and Recovery in Football
}

\section{Futbolda Yorgunluk ve Toparlanma}

\author{
Şefika Kiziltoprak \\ Sports Medicine Department, İstanbul Physical Therapy and Rehabilitation Education and Research Hospital, İstanbul, Turkey
}

Ş. Kiziltoprak

0000-0002-3439-8665

Geliş Tarihi/Date Received: 06.02.2019

Kabul Tarihi/Date Accepted: 20.08.2019

Yayın Tarihi/Published Online: 28.11.2019

\section{Yazışma Adresi /}

Corresponding Author:

Şefika Kiziltoprak

T.C. Sağlık Bakanlığ 1 İstanbul

Fizik Tedavi Rehabilitasyon

Eğitim ve Araştırma Hastanesi, Spor Hekimliği Kliniği,

İstanbul, Türkiye

E-mail:

kiziltopraksefika@gmail.com

(C)2020 Türkiye Spor Hekimleri Derneği. Tüm hakları saklıdır.

\section{ABSTRACT}

In professional football, players are generally expected to participate in more matches than before. Therefore, they may occasionally fail to show their best physical performance. Due to intense match schedules; to reduce post-match fatigue to optimize performance as quickly as possible and to minimize the risk of injury appropriate recovery strategies are necessitated.

Football requires some activities such as sprinting, changing direction, jumping, grabbing the ball as well as technical skills for example dribbling, passing, shooting the ball. All of these activities are resulted with fatigue with a combination of dehydration, deprivation of the glycogen storage, muscle injury and mental exhaustion. The amount of fatigue depends on many internal and /or external factors and influences recovery process.

In football, recovery strategies are complex and many of the proposed methods are still controversial. Sleep, hydration, diet and cold water applications are the most evident strategies. Further studies are needed to clarify the factors those leading to and determining the level of fatigue, thus implementing effective and individualized recovery strategies.

Keywords: football, fatigue, recovery

\section{ÖZ}

Günümüzde profesyonel futbolda, sporcuların genellikle eskisine göre daha sık aralıklarla maçlara çıkması beklenir. Bu sebeple fiziksel performanslarını tam olarak göstermekte zaman zaman başarısız olabilirler. Bu yoğun maç programları sırasında maç sonrası yorgunluğu hafifletmek, performansı en hızlı şekilde optimuma getirmek ve yaralanma riskini en aza indirmek; uygun toparlanma stratejilerini gerektirir.

Futbol; sürat koşusu, yön değiştirme, zıplama, topu kapma gibi aktivitelerin yanı sıra top sürme, pas verme, şut atma gibi teknik beceriler de gerektirir. Tüm bu aktiviteler; dehidratasyon, glikojen depolarının boşalması, kas hasarları ve mental yorgunluğun bir kombinasyonu olan maç sonu yorgunluğa neden olur. Futbol maçı sonrası yorgunluğun dozu, içsel ve veya dışsal birçok faktöre bağlıdır ve bu faktörler toparlanma süreci üzerinde etkilidir.

Futbolda toparlanma stratejileri karmaşıktır ve önerilen yöntemlerin birçoğu halen tartışmalıdır. Uyku, hidrasyon, diyet ve soğuk su uygulaması etkinliği daha iyi gösterilmiş yöntemler arasında yer almaktadır. Yorgunluk mekanizmasını ve seviyesini etkileyen diğer faktörleri belirlemek için daha fazla çalışmaya intiyaç vardır. Etkin ve bireysel olarak dizayn edilen toparlanma stratejileri bu şekilde hayata geçirilebilir.

Anahtar sözcükler: futbol, yorgunluk, toparlanma 
Available at: http://journalofsportsmedicine.org and http://dx.doi.org/10.5152/tjsm.2020.174

Cite this article as: Kiziltoprak S. Fatigue and recovery in football. Turk J Sports Med. 2020;55(2):172-85.

\section{GİRIŞ}

Yorgunluk, kas aktivitesi ile ilişkili performansta azalma olarak tanımlanabilir (1). Tek bir maç sonrası meydana gelen akut yorgunluk, saatler ve günler içinde gelişen fiziksel performans düşüşleriyle karakterizedir (2,3). Birkaç çalışmada, elit sporcularda maç öncesi fiziksel performans değerlerine ulaşma, kas hasarı ve inflamasyonun iyileşmesi için 72 saatten uzun bir zamana ihtiyaç olduğu rapor edilmiştir (2-4). Birkaç hafta devam eden 3-4 günde bir maçın olduğu yoğun dönemler, onarım ve toparlanma için gereken süreyi yetersiz kılabilmektedir. Dolayısıyla sporcular performans düşüklügü ve/veya yaralanmalara yol açabilecek akut ve kronik yorgunluk deneyimleyebilirler. Futbol maçı sonrası yorgunluğun dozu, iç (maç sonucu, rakip takımın seviyesi, maçın yapılacağı yer, maçın oynandığı zemin vb.) ve dıș faktörler (antrenman durumu, yaş, cinsiyet, kas liflerinin dağılımı vb.) toparlanma süresi üzerinde etkilidir.

Yoğun maç programlarının olduğu dönemlerde, performansın hızlı bir şekilde optimuma ulaşabilmesi ve yaralanma riskini minimuma indirmek açısından toparlanma stratejileri önem kazanır. Ancak, günümüzde toparlanma stratejileri üzerinde fikir birliği yoktur. Etkin ve bireysel olarak tasarlanmış toparlanma stratejileri için daha ileri çalışmalara ihtiyaç vardır.

$\mathrm{Bu}$ derlemede, yorgunluğun sebepleri ile birlikte oluşum mekanizmaları ve güncel toparlanma stratejileri özetlenmiştir.

\section{Maç Sonrası Yorgunluk}

Maçla ilişkili yorgunluk; merkezi sinir sistemi, kas hücrelerinin kendisi ve enerji sistemlerini de kapsayan santral ve periferik faktörlerin bir kombinasyonudur (5). Yorgunluk üzerine etkili olduğu bulunmuş olan belli başlı faktörler; dehidratasyon, glikojen tükenmesi, kas hasarı, mental yorgunluk olarak sıralanabilir.

\section{Dehidratasyon}

Futbolun kuralları gereği maç sırasında futbolcuların kaybettikleri sıvıyı yerine koyma olanak- ları sınırlıdır. Bu sıvı kaybının derecesi ortam sıcaklı̆̆l, rüzgar, vücut sıcaklığ seviyesinden yükseklik gibi durumlara göre değişir.

Vücutta isı stresine neden olan sıcaklık ve nem seviyesi, $25^{\circ} \mathrm{C}$ ve $\% 60$ nemin üzerindeki değerler olarak ifade edilmiştir (6). Ortam sıcaklığının yüksek olduğu $\left(31.2-31.6^{\circ} \mathrm{C}\right)$ durumlarda maç sonrası net sıvı kaybının vücut kitlesinin \%2'sinden fazla olduğu gösterilmiştir (7). Optimal ortam sıcaklığında $\left(21-24^{\circ} \mathrm{C}\right)$ yapilan futbol maçlarında dahi yaklaşık \%2'lik sıvı kayıpları saptanmıştır $(2,8)$.

Hafif dehidratasyonun $(<\% 2)$, anaerobik performansı sekteye uğratmamakla birlikte (9), teknik beceriler (9) ve bilişsel performans $(10,11)$ üzerine olumsuz etkileri gösterilmiştir. Dehidratasyon, dayanıklılık performansını da olumsuz etkilediğinden, sıvı takviyesinin zamanlaması önemlidir. \%2'lik sıvı kaybına neden olan efor sonrası sıvı takviyesi, sıvı kaybının \%150'si miktarında ve sodyum konsantrasyonu 61 mmol/L olacak şekilde önerilmektedir. Protokollere uygun olarak yapılan sıvı takviyesi ile 6 saat gibi görece kısa bir sürede sıvı kaybı kompanse edilebileceği için, dehidratasyonun yorgunluk üzerindeki etkisinin sinırlı olabileceği söylenebilir (12). Ancak, hücre içi sıvı volümünün azalması, glikojen ve protein sentezi hızını azaltacağı için, sıvı takviyesi maç sonu toparlanmada belirleyici bir faktördür (13).

Dehidrasyonun vücut ısısını yükseltebileceği ve bu durumun hipertermiye zemin hazırlayacağı savunulmuştur. Egzersiz sırasında dehidrasyon ve hiperterminin etkilerinin incelendiği bir kontrollü çalışmada, dehidratasyon ve hipertermi etkileşiminin hareket teknikleri üzerine olumsuz etkileri gösterilmiştir. Ayrıca, ortam sıcaklığındaki artışın, denge duyusunu bir yönüyle zayıflattığı da ifade edilmiştir (14). Egzersiz stresi nedeniyle artmış vücut ısısının, vücut farkındalığı ve karar yeteneğine zarar vererek alt ekstremite yaralanmalarına zemin 
hazırlayabileceği savunulmuştur (15). Ancak, sıcaklık artışının, hipertermi yokluğunda periferik yorgunluk üzerine etkisi gösterilememiştir $(16,14)$.

\section{Glikojen tükenmesi}

Futbolda maç sonuna doğru ortaya çıkan glikojen depolarındaki boşalma, yüksek yoğunluk düzeyinde kat edilen mesafedeki düşüşte önemli bir etken olarak ortaya çıkar $(17,18)$. Krustrup (19), kaslardaki glikojen yoksunluğunun tek ya da tekrarlı sprint koșularında maksimum efora çıkılmasını önleyebileceğini bildirmiștir.

Yüksek seviyede bir futbol maçı sonrası kas glikojen depolarının doldurulması süreci, 2-3 günü bulmaktadır. Jacobs (17), İsveçli üst düzey elit futbolcularda, kas glikojen konsantrasyonunun maçtan 2 gün sonra maç öncesi değerlerin $\% 50$ 'si düzeyinde olduğunu göstermiştir. Yüksek karbonhidrat diyeti uygulanan üst düzey elit Danimarkalı futbolcularda yapılan başka bir çalışmada, maçın hemen sonrası ve 24 saat sonrası kas glikojen düzeylerine bakılmış ve maç öncesi değerlerle kıyaslandığında, sırasıyla \%43 ve $\% 27$ oranında azaldı ğı saptanmıştır. 48 saat sonra ise, glikojen seviyeleri maç öncesi seviyelere yakın bulunmuştur (19).

\section{Kas hasarl}

Futbol maçı sırasında sprint, yön değiştirmek için kısa mesafede hız düşürme, topa vurma, şut atma, atlama ve maksimal sıçramalar ya da rakiple direkt temas gibi aktiviteler sıklıkla tekrarlanır. Bu aktiviteler sırasında çok sayıda eksantrik kas kasılmaları olur ve bu durum kas hasarları için potansiyel oluşturur. Özellikle de yön değiştirme, ani hızlanma ve yavaşlamalar kas hasarı riski taşır (20).

Kas hasarının ciddiyeti, az sayıda kas lifinin eşlik ettiği mikro yaralanmadan, kasın tüm liflerinin etkilendiği tam bir kas yırtığına kadar değişebilir. Kas hasarı; kas fonksiyonunda geçici azalma, kanda hücre içi proteinlerin artışı, kas ağrısı ve dahil olan kas grubunda şişme ile karakterizedir. Kas hasarını izlemede kullanılan parametreler; maksimal istemli kontraksiyon kuvveti, kreatin kinaz (CK) ve miyoglobin düzeyleri, kas ağrısı, eklem hareket açıklığı ve şişlik olarak sıralanabilir. Ayrıca, kas hasarı maç sonrası performansla bağlantılı olarak toparlanma sürecini bozabilir. 2 gün eksantrik egzersiz programı uygulanan sporcularda, hasarlanmış kasın glikojen içeriği, hızlı kasılan liflerin baskın etkisiyle kontrol grubuna göre düşük seviyede bulunmuştur (21).

\section{Mental yorgunluk}

Futbol karşılaşması sporcularda fiziksel zorlanmanın yanı sıra uzun süreli odaklanabilme, algılama düzeyini sürdürebilme gerekliliği, rakip baskısı altında karar verebilme zorluğu gibi türlü psikolojik streslere de yola açabilir. Maç sırasında taktik ve strateji konusundaki sürekli değişkenlik, oyuncuları teknik kabiliyet ve fiziksel kapasite açısından zorlayabilir.

Bilișsel açıdan zorlayıcı uzun süreli bir görev siklıkla mental yorgunluğa yol açar ve performansı etkiler. Yorulmuş olan katılımcılar hala iyi öğrenilmiş ve otomatikleşmiş yeteneklerini gösterebilseler de yoğun dikkat gerektiren durumlarda performanslarının belirgin olarak sekteye uğradığı rapor edilmiştir (22). Futbola özgü aralıklı aktivitelere fizyolojik cevaplar açısından gözlemlenen ve devamlı uyanıklılık görevi verilen sporcularda ikinci yarının son 30. dakikalarında çok sayıda hata saptanmıştır (23). Bu çalışmanın verilerinden mental yorgunluğun fiziksel performansı da etkileyebileceği sonucu çıarılabilir.

Diğer yandan egzersiz sırasında meydana gelen fizyolojik değişikliklerin (örneğin; plazma glikoz seviyesi, vücut sıcaklığı ve hidrasyon durumu), bilişsel fonksiyonlar üzerine de dolaylı olarak etkili olabileceği gösterilmiştir (10).

Sporcular için yolculuğun getirdiği stres ve olumsuz koşullar da mental yorgunluğu tetikleyebilen bir başka faktör olarak karşımıza çlkabilir. Sirkadyen ritimdeki sapmalar (jet lag ya da gidilecek yere gece ulaşma gibi), yolculuk sırasında kısıtlı hareket imkanı alışık olunmayan ortamlarda uyuma ve düşük uyku kalitesi de yolculuğun getirdiği olumsuz etkiler olarak sayılabilir (24).

Fikstür çok yoğun olduğunda, sporcuların mental toparlanmaları için ayrılan zaman yetersiz 
kalabilir. Bu durum, konsantrasyon eksikliği ve mental yıkıma yol açabilir. Nederhof ve ark.'nın (25) derlemesinde kronik yorgunluğun bilişsel performansa etkileri açıklanmıştır. Maç sonucunun da (kazanma ya da kaybetme), maç sonrası duygu durumu ve mental yorgunluk üzerine etkili olabildiği belirtilmiştir.

\section{Futbol Maçının Tetiklediği Yorgunluk Düzeyi ve Toparlanma Sürecindeki Belirteçler}

Toparlanma süreci, sporcunun performans seviyesinin referans seviyesine ulaşması ile son bulur. Yoğun maç dönemlerinde toparlanma için 2 maç arasında kalan süre 72 saate inebilir ve bu süre fiziksel performansı normale getirmek için sıklıkla yetersiz kalır (22).

\section{Yorgunluk Düzeyi}

Sprint performansının egzersizin hemen sonrasında \%2-9 aralığında azaldığı gösterilmiștir. Toparlanma döneminde sprint performansının geri kazanılması için gereken süre literatürde 5 saatten (2) 96 saate kadar (3) değișen değerlerde rapor edilmiştir.

Sıçrama performansının egzersizin hemen sonunda \%0-12 oranında düştüğü; bu düşüşün toparlanma süresinin ise 48 saatten 72 saatin üzerine kadar değiştiği bildirilmiştir (22).

Diz fleksör/ekstensör maksimal istemli kontraksiyon kuvveti bir toparlanma belirteci olarak kullanılmaktadır. Diz fleksör kuvvetlerinde \%036 , ekstensör kuvvetlerinde $\% 0-25$ oranlarında azalma belirlenmiştir (22).

Fiziksel performans sadece sporcuların fit olma durumuna göre değil, maçın sonucuna (örneğin; maçı kazanma, kaybetme veya berabere kalma), rakip takımın kalitesine (güçlü ya da zayıf) ve ayrıca maç lokalizasyonuna (kendi evinde veya deplasmanda) göre de değişebilir. Maçın doğası da (dostluk, ulusal, uluslararası vb.) benzer şekilde sprintlerin sayı ve yoğunluğunu, maç sırasında rakiple girilen ikili mücadeleleri ve sürdürülen konsantrasyonun yoğunluğunu değiştirebilir. Etken olan diğer dış faktörler ise; hava şartları ve sahanın yapısı (çim, toprak, karlı, suni çim) olarak sıralanabilir (22).
Futbolda yorgunluğun dozu değișkenlik göstermektedir. Ani hızlanma, yavaşlama, yön değiştirme gibi farklı futbol aktiviteleri ve oynanan zeminin türü tek başına maçın neden olduğu kas zorlanmalarını ve toparlanma periyodunu etkilemeyebilir. Ancak tüm bu faktörler bir araya geldiğinde, yorgunluğun dozu maçtan maça büyük değişim gösterebilir. Yaş, kas liflerinin dağılımı, antrenman durumu gibi içsel faktörler, aynı takım içinde toparlanma süresindeki kişisel farklılıkları açıklamaya yardımcı olur. Saptanan içsel faktörler, kişiye özel toparlanma protokolleri geliştirmede önem taşır.

\section{Fiziksel performans belirteçleri}

Fiziksel performans belirteçleri toparlanma döneminde sportif aktiviteye optimum katılım zamanını belirlemekte yol gösterici olabilir:

20 m sprint koşusu: Futbol maçı sonrası toparlanma sırasında en yaygın kullanılan değerlendirme parametresidir (22).

Tekrarlı sprint koşusu: Sporcunun maçtan sonraki gün yüksek tempodaki aralıklı aktiviteleri kaldırabilme yeteneğini ölçer. Çok çeşitli tekrarlı sprint testleri kullanılmaktadır. Toplam sprint süresi değerlendirilir (22).

Tekli sprint test ve tekrarlı aralıklı sprint testleri ile ilgili ileri bilimsel çalışmalar hala devam etmektedir. $\mathrm{Bu}$ testlere toparlanma döneminde çeviklik ölçümleri de dahil edilebilir (26).

\section{i) Sıçramalar}

Sıçrama performansı futbolda önemli bir tanımlayıcıdır:

Squat jump (SJ) ve Counter movement jump (CMJ) testleri değerlendirilen ana zıplama testleridir ve anaerobik kapasite tayini için kolay ve hızlı uygulanabilme özelliğindedir.

Vertical jump (dikey sıçrama) yüksekliği, maksimal kuvvet düzeyi ile iyi korelasyon gösterir.

5 jump test: İleriye doğru bacak değiştirerek 5 kez sıçrama temeline dayanır. Nöromusküler yorgunluk ile değişime uğrayan patlayıcı kuvvetin değerlendirilmesini sağlar.

Üç adım öne sıçrama testi: Dominant bacak üzerinde ileriye doğru 3 maksimal sıçramadan olu- 
şur. Belirli bir zaman periyodu içinde yapılan sıçrama sayısı değerlendirilir. Sporcunun alt ekstremite kuvvet ve güç seviyesini belirlemek için uygun bir testtir (22).

\section{ii) Maksimal istemli kuvvet}

Maça bağlı maksimal istemli kuvvette azalma, merkezi ve periferik faktörlerin bir kombinasyonu olarak hemen maç sonrası ve toparlanma süreci boyunca ortaya çıkar. Merkezi yorgunluk, ana etken olarak ortaya çlkarken, periferik yorgunluk kas hasarı ve inflamasyon üzerinden etkili görünmektedir (27).

Warren ve ark. (28), maksimal istemli kas kontraksiyonunun kas hasarını ortaya koymada en güvenilir yöntem olduğunu savunmuşlardır. Birçok araştırmacı diz ekstensörlerine göre diz fleksörlerindeki kuvvet kaybının, futbol sonrası gelișen yorgunlukta daha belirgin olduğunu gözlemlemiştir (22). Diz fleksörlerinin yorgunluğa daha yatkın olması, bu kasların neden daha fazla hasara uğradığını da açıklamaktadır (toplam yaralanmaların \%12'sini oluştururlar) (29). En yüksek oranda yaralanmanın ise her iki yarının son 15 dakikasında meydana geldiği belirlenmiştir (30).

Maç sonrası fonksiyonel hamstring/kuadriseps oranında gözlemlenen belirgin azalma (22) da toparlanma periyodunda sporcuların yaralanma riskini değerlendirmek açısından anlamlıdır.

\section{iii) Esneklik}

Esnekliğin performans ve yaralanma riskine etkileri ile ilgili çelişkili sonuçlar bulunmaktadır (22). Ancak, eklem hareket açılılı̆ının optimum düzeyde olmamasının fonksiyonel bozukluklarla sonuçlanarak kas hasarına yol açabileceği genel kabul gördügünden, çeşitli esneklik testleri de (otur-eriş testi gibi) geniş kullanım alanı bulmaktadır. Ispirlidis ve ark. (3) diz eklem hareket açıklığını bir toparlanma belirteci olarak kullanmıştır. Maç sonrası 48 saat içinde diz ROM değerlerinin azaldığını rapor etmişlerdir.

\section{iv) Aerobik performans}

Futbol genel olarak aerobik metabolizmaya bağımlı bir oyun olarak sınıflandırılabilir. Toparlanma sürecinde aerobik performans değerlen- dirilirken, yorgunluğun sonuçları etkileyebileceği dikkate alınmalıdır. Tekrarlı sprint testleri gibi farklı protokoller de aerobik fitnes düzeyini indirek olarak değerlendirmede önerilmektedir (22).

\section{v- Teknik yetenekler}

Futbolda başarı pas verme, şut atma, çalım atma gibi becerilerle birlikte tanımlanır. Beceri testlerinde pas verme, şut atma ile ilişkili değerlendirmeler kullanılmaktadır; egzersiz sonrası yorgunluktan en fazla şut atma performansinın etkilendiği, bunu çalım atma ve pas verme yeteneklerinde azalmanın izlediği görülmüştür (31).

Yorgun sporcular, doğru tekniği kullanmada zorlanabildiğinden beceri isteyen eylemlerde yaralanma riski artış gösterebilmektedir. Özellikle şut atma başta olmak üzere, beceri isteyen teknik hareketler değerlendirilerek toparlanma sürecinin yeterliliği ile ilgili yorum yapılabileceği düşünülmektedir.

\section{Bilișsel fonksiyon}

Algısal yetenekler (örneğin; reaksiyon zamanı, karar verme, görsel tarama, uzaysal farkındalık ve sezgi) üst düzey futbola özel talep edilen yetenekler içindedir. Nederhof ve ark.'nın (25) önerdiği psikomotor hız testi (stres altında "Vienna determination test") bozulmuş stres rejenerasyon dengesinin erken tespiti için önerilmiştir.

Yorgunluk, hata sayısında ve reaksiyon zamanında artışa neden olur (32). Maça bağlı olarak gelişen mental yorgunluğun toparlanma sürecinde psikomotor hız performansı üzerine etkileri konusunda ileri çalışmalara ihtiyaç vardır. Sonuç olarak, psikomotor hız ekstra toparlanma test belirteci olarak kullanılabilecek potansiyeline sahiptir.

\section{Subjektif belirleyiciler}

Subjektif bir faktör olan, kas ağrısındaki değişim, toparlanmanın değerlendirilmesinde geçerli bir belirteçtir. Futbolda toparlanma süresi ile ilgili ölçümler subjektif kas ağrısı yoğunluğu nedeni ile daha çok alt ekstremite kaslarında yapılmıştır (3). Bununla birlikte futbolcular egzersiz sonrası hemen ortaya çıkan bir kas ağrısı 
ifade edebilirler. Kas ağrısı, genellikle egzersiz sonrası 24-48 saatte pik düzeye ulaşır ve bu durum geç başlayan kas ağrısı (delayed onset muscle soreness; DOMS) olarak bilinir (33). Subjektif de olsa bu şikayetler toparlanma düzeyinin takibi açısından önemlidir.

Toparlanma sürecine farklı açılardan baktığımızda, uyku kalitesi, yorgunluk ve stres ek olarak değerlendirilebilir. Psikofizyolojik toparlanmanın ölçümü için sporcuların günlük yaşam talepleri analizi (The daily analysis of life demands for athletes) anketi de yorgunluk ve toparlanma durumundaki günlük değişimleri belirlemek için kullanılabilir (34).

\section{Biyokimyasal belirleyiciler}

Antrenman ve maçların tetiklediği fiziksel değişikliklerin biyokimyasal olarak izlenmesi, bireysel antrenman yüklenmeleri ve dolayısıyla yorgunluk düzeyleri üzerine önemli bir değerlendirme yöntemidir.

İskelet kas lifleri hasarlandığında, kas proteinleri, kreatin kinaz (CK) ve miyoglobin kas liflerinden plazmaya sızar. Egzersizin hemen sonrasında CK konsantrasyonu \%70-250 arasında artış gösterir ve 24-48 saatte pik yapar. 48-120 saat içinde, düzeyin yüksekliğine bağlı olarak bazal değerlere iner. Sporun kontakt ya da nonkontakt olmasına bağlı olarak farklılıklar görülebilir (22).

CK düzeyinin kas hasarını değerlendirmedeki geçerliliği tartışmalı olup, yüksekliği diğer proteinlerle ilişkilidir. Ayrıca, 24 saat içinde normal değerlere dönen miyoglobine karşın, CK birkaç gün yüksek kalabilmektedir (22).

Profesyonel futbolcuların günlük antrenman programı olduğundan, bazal CK değerlerini sağlamak güçtür ve dinlenim değerleri de yüksek seyretmektedir. Bu sebeple, Mougios (35) erkek futbol oyuncuları için spektrofotometrik analizle ölçülen referans CK değerlerini önermiştir. (83$1492 \mathrm{U} / \mathrm{L}, 37^{\circ} \mathrm{C}$ 'de) Cinsiyet farkı referans CK düzeyini etkilemekte olup, erkeklerde bu değerler daha yüksektir, ancak yaşla (7-44 yaş aralığında) bir ilişki saptanamamıştır.

Kas hasarı lokal inflamatuvar cevabı başlattığ için sitokin üretimi uyarılmaktadır. Günlerden haftalara kadar uzanan kas onarımı, yenilenme ve gelişimi bu şekilde meydana gelir (36). Bu sitokinler, inflamasyon hücrelerinin kasa hızla invazyonunu sağlarlar. Böylece, doku hasarına akut faz cevabı olarak adlandırılan bir sistemik cevap oluşur.

Salgısal $\lg$ A (slgA), fiziksel aktivitenin bağışıklık sistemi üzerine etkilerini görüntülemede en sık kullanılan belirleyicilerdendir ve özellikle üst solunum yolu enfeksiyonu riski ve bu durumun antrenman performansı üzerine olumsuz etkileri ile ilişkilendirilmiştir. (37)

En fazla miktarda üretilen sitokin olan Interlökin 6 (IL-6) diğer sitokinler için inflamasyon kaskadında öncü rol oynar. IL-6, hemen maç sonrası pik yapar ve 24 saat içinde hızlıca maç öncesi değerlere geriler (3).

Artmış akut faz; C-reaktif protein (CRP) düzeyi, egzersiz sonrası 48 saate kadar devam edebilir. Kontakt durumlarda meydana gelen kas hasarında artış gösteren CRP'nin CK, miyoglobin ve laktat dehidrojeneza (LDH) göre daha sensitif olduğu kabul görmektedir (38).

Bir futbol maçı sırasında, iskelet kaslarındaki yüksek mitokondriyal oksijen tüketimi ile meydana gelen iskemi-reperfüzyon durumu, reaktif oksijen radikallerinin (ROS) üretimine neden olur. Kas yaralanması sonucu oluşan inflamasyon da bu üretime katkıda bulunur. Yüksek ROS üretimi sonucu antioksidan kapasite aşıldığında, vücutta oksidatif stres meydana gelir ve dolayısıyla kas rejenerasyonu sıkıntıya uğrar (4).

Ürik asitin oksidatif stres belirleyicisi olarak kullanımı yaygındır, çünkü egzersiz sırasında artan antioksidan kapasitesinin üçte birine denk gelir (3). Ürik asit düzeyleri egzersizin hemen sonrasında \%0-75 aralı̆̆ında artar ve 96 saate kadar yüksek kalır. Ürik asite ek olarak diğer birçok oksidatif stres belirteci üzerinde çalışılmıştır (3), ancak henüz pratikte kullanımları sınırlıdır.

Futbol maçı sonrasında sporcuların hormon düzeylerinde de değişimler saptanmıştır. Değişime uğrayan hormonlardan biri olan kortizolle ilgili çalışma sonuçları tartışmalı olup (3) cevapların 
kişiler arasında ve bireyin kendi içinde büyük varyasyonlar gösterdiği belirtilmiştir.

Genç erkeklerde futbol maçı sonrasında düşen testosteron konsantrasyonlarının, maç sonrası 72 saatte hala düşük düzeyde olduğu saptanmıştır (39). Yorgunluğun derecesini belirlemek açısından planlanan, Maso ve ark.'nın (40) rugby oyuncuları üzerindeki çalışmalarında, anabolik bir hormon olan testosteron düzeyindeki değişimleri izlemenin, katabolik bir hormon olan kortizoldeki değişimleri izlemekten daha anlamlı olduğu savunulmuştur.

Sonuç olarak, testosteron ve kortizol, protein yapım ve yıkımındaki değişimler üzerinden doku onarımını gözlemlemek amacıyla sıkça kullanılmaktadır $(37,41)$. Testosteron anabolik bir hormonken, kortizol major katabolik hormondur (41). Kortizol, egzersizle birlikte artış gösterir ve 1.5-4 saat içinde normal değerlere gelir. Bağışıklık sistemi, bağ doku ve iskelet kaslarındaki yeniden modelleme ve onarım sürecinde bu iki hormonun homeostatik stabilite içinde normal dengesine dönmesi önem taşır. (41) Testosteron/Kortizol (T/C) oranı zindelikyorgunluk düzeyinin bir belirteci olarak overtraining (aşırı antrenman) sendromunu önlemek amacıyla kullanılabilmektedir. Ayrıca, T/C düzeyleri tükenme așamasına gelmeden optimum fiziksel uygunluğu belirleme amaciyla da kullanılmaktadır (37).

\section{Toparlanma Stratejileri}

Günümüzde uygulanan toparlanma stratejileri; beslenme, soğuk uygulaması, düzenli uyku, aktif toparlanma, fleksibilite, basınç giysileri, masaj ve elektriksel stimülasyon yöntemleri olarak sıralanabilir. Bazılarının yorgunluğa karşı koymada etkinliklerinin (hidrasyon, beslenme, uyku gibi) daha fazla olduğu gözlemlenmektedir.

Sporcuların, müsabaka sonrasında bir sütlü içecek ve takip eden 1 saat içinde yüksek glisemik indeksli ve protein içerikli bir ögün yemeleri, maç sonrası depoları doldurmak ve kas hasarı onarımını optimize etmek için önerilmektedir. Uyku, toparlanma aşamasının esas parçasını oluşturur. Maç sonrası uyku bozukluğu sıktır ve toparlanmayı negatif etkileyen bir faktördür.
Soğuk su uygulaması, maç programlarının sıkışık olduğu dönemlerde performansı artırmak, akut inflamasyonu baskllamak için yaygın olarak uygulanır. Diğer yöntemlerin (fleksibilite, basınç giysileri, masaj, elektrik stimülasyon) toparlanmayı kolaylaştırmadaki bilimsel kanıtları daha zayıftır.

\section{i) Beslenme}

Futbol maçı ardından gelişen dehidratasyonda (vücut kitlesinin yaklaşık \%2'sinin kaybı), sıvı kaybının \%150-200'üne denk gelecek miktarda yüksek sodyum içeren bir içecek alınması (61 mmol/L) 6 saat sonunda sivi kaybinı ortadan kaldırmak için yeterlidir (12).

Kas glikojen depolarının yeniden sentezini optimize etmek için, maç sonunda yüksek glisemik indeksli (GI) karbonhidrat alımı gereklidir. Yaklaşık $1.2 \mathrm{~g} / \mathrm{kg} /$ saat yüksek GI'li karbonhidrat maçın hemen sonrasında ve 5 saate kadar aralıklı olarak (42) alındığında, glikojen depolarını maksimuma çıkarmak mümkündür. Ancak yüksek GI'li karbonhidrat içeren öğünlerin futbol performansı üzerindeki etkinliği kesin değildir. Düşük miktar karbonhidrat protein $(0.4$ $\mathrm{g} / \mathrm{kg} / \mathrm{saat}$ ) ile birlikte tüketildiğinde insülin salgısını ve egzersiz sonrası glikojen sentezini artırır, dokulara glikoz alımı ve kas glikojen sentezinde artışı da beraberinde getirir (42). Bunun aksine, Gunnarsson ve ark. (43), maç sonrası whey proteini ve karbonhidrattan zengin diyet ile normal diyeti kıyaslamışlar, 48 saat sonra glikojen sentezinde artış görememişlerdir.

Egzersiz kas protein sentezi ve protein ylkımını uyardığından, egzersiz sonrası protein alınmaması negatif protein dengesine yol açabilir. Aslında, egzersizin tetiklediği kas hasarının onarımı pozitif protein dengesini gerektirmektedir. Kas protein sentezini uyarmak için ne zaman ve ne miktarda protein alınması gerektiği de tartışmalı bir konudur. Egzersiz sonrası ilk 2 saatte alınacak 20 g süt proteini veya eşdeğer 9 g aminoasit alımının yeterli olduğu görüşü hakimdir (44).

Dallı aminoasitlerden zengin yüksek protein içeren bir diyetin yorgunluk hissi ve mental performans üzerinde olumlu etkileri olduğu düşünülmektedir (45). Egzersiz sonunda karbonhid- 
ratlara ek olarak protein alımı kas ağrıları, CK konsantrasyonu ve miyoglobin konsantrasyonunda azalmaya neden olabilmektedir. Basit karbonhidratlı içecek ile kıyaslandığında, ardışık kas fonksiyonlarında iyileşme sağladığı da gösterilmiștir (46).

Süt maç sonrası kolay ulaşılabilir bir ürün olmasıyla etkin bir içecek olarak görünmektedir. Karbonhidrat ve protein içerdiğinden, egzersiz sonrası toparlanmada olumlu etkisi gösterilmiştir. Maç ve antrenman sonrası çikolatalı süt alımı ile egzersiz performansı, hücre içi protein sentezi sinyal uyarımı, algılanan ağrı düzeyi ve CK seviyeleri arasında ilişkilerin değerlendirildiği çalışmalar vardır $(46,47)$.

Diyetle omega 3 yağ asitleri, zerdeçal, vişne suyu ve domates suyu alımının antiinflamatuar ve antioksidan etkileri nedeniyle toparlanma sürecini iyileştirdiği düşünülmektedir. Kanda artmış omega 3 konsantrasyonunun, proinflamatuar sitokinlerin (IL-6, IL-1ra, TNF- $\alpha$, CRP) seviyelerinde azalma ve anti-inflamatuar sitokinlerin (çözünebilir IL-6r, IL-10, TGF- $\beta$ ) düzeylerinde artışa sebep olduğu gösterilmiştir (48).

Tartibian ve ark. (49), 30 gün $1.8 \mathrm{~g} /$ gün omega 3 yağ asidi desteğinin egzantrik diz ekstansör egzersizlerinden 48 saat sonraki alt ekstremite kas ağrısı üzerine olumlu etkisini göstermişlerdir. Bu çalışmada elde edilen bulguların antiinflamatuar etki nedeniyle ortaya çıktığı savunulmuştur. Ancak, omega 3 yağ asitlerinin fiziksel performans üzerindeki olumlu etkileri henüz netlik kazanmamıştır. Omega 3 yağ asitlerinin somon, uskumru ve hamsi gibi balıkların diyetle alımıyla sağlanabileceği vurgulanmaktadır (47).

Zerdeçal antiinflamatuar etkinlik sergileyen bir diğer ürün olup, hayvan deneylerinde IL-1b, IL6 , TNF- $\alpha$, CK gibi inflamatuvar sitokin ve enzimlerin etkinliğini azalttığ gösterilmiştir (50). Ancak egzersiz sonrası toparlanmaya etkisi konusunda daha fazla çalışmaya ihtiyaç vardır.

Vişne suyunun toparlanma döneminde yapısındaki antosiyaninlerin etkisiyle anti inflamatuar ve antioksidan özellik gösterdiği ve sekonder kas hasarı cevabını baskıladığı düşünülmektedir (51).
Domates suyunun likopen içeriği nedeniyle oksidatif stresi azalttığı ve performansı olumlu etkilediği gösterilmiştir (52).

Alkol tüketimi toparlanma sürecini negatif etkileyebilecek bir faktördür. Sporcular maçtan sonraki saatlerde nadiren orta-yüksek miktarda alkol (etanol) tüketir. Maç sonrası dönemde kas fonksiyonunun iyileşmesi ve toparlanma dönemindeki kayıpları önlemek için futbolcuların alkol tüketiminden kaçınmaları önerilmektedir. Alkolün kas onarımındaki olumsuz etkilerinin yanı sıra, toparlanma döneminde dehidratasyonun düzelmesini de zorlaştıracağı vurgulanmaktadır (47).

\section{ii) Soğuk uygulama}

Soğuk su uygulamasinın egzersizin hemen sonrasında yapılması ve toparlanma döneminde tekrarlanmasının pasif toparlanma, kontrast su banyosu ve sıcak su uygulamalarına göre daha üstün olduğu gösterilmiștir (53).

Maç sonrası $9-10^{\circ} \mathrm{C}^{\prime}$ de $10-20$ dakika uygulanan soğuk suyun, anaerobik performans (maksimum kuvvet, sprint yeteneği, counter movement jump (CMJ)) üzerinde pozitif etkileri rapor edilmiştir (54). Ayrıca kas ağrısında azalma, CK ve miyoglobin konsantrasyonlarında düşme de gözlenmiştir (55).

Soğuk su uygulama protokollerinde sıcaklık, süre ve suya batırılma seviyesi açısından en etkin yöntem henüz tanımlanmamıştır. $10-15^{\circ} \mathrm{C}^{\prime}$ de 5 15 dakika soğuk su uygulamasının maksimal kuvvet, sprint, bisiklet performansı, kürek performansı üzerine olumlu etkileri olduğu ve ödemi de azalttığı rapor edilmiştir (47).

Brophy-Williams ve ark. (56) soğuk su uygulamasinın hemen egzersiz sonrasinda yapılmasının, 3 saat sonra yapılmasına göre ertesi günkü koşu performansında daha etkili olduğunu göstermişlerdir.

Toparlanma sürecinde $15^{\circ} \mathrm{C}^{\prime}$ de 15 dakika tüm vücut soğuk su uygulamasıyla kan akışının kol ve bacaklardan gövdeye doğru yöneldiği, venöz dönüşün artışıyla kardiyak etkinliğin arttığı gözlenmiştir (57). 
Soğuk su kas hasarından kaynaklanan akut inflamasyonu azaltıp kısa dönem analjezik etki sağlayabilir. Kesin kanıt olmamakla birlikte, soğuk uygulaması sonucu iskelet kaslarında kan akımı yavaşladığından, kaslarda egzersiz sonrası glikojen sentezinin yavaşlayabileceği düşünülmekte$\operatorname{dir}(47)$.

Düzenli soğuk su uygulamasının, kaslarda egzersize bağlı adaptasyonu baskıladığı (ısı-şok proteini supresyonu üzerinden vaskülariteyi ve uzun dönemde kassal adaptasyonları engellediği) öne sürülmüştür (58).

Soğuk suyun olası olumlu ve olumsuz yönleri göz önüne alındığında, maç takviminin yoğun olduğu dönemlerde kas ağrılarını azaltıp fiziksel performansı iyileştirdiği söylenebilir. Bunun dışında, onarım ve adaptasyon sürecini sekteye uğratmamak için uygulanmamalıdır (47).

\section{iii) Uyku}

Uyku fonksiyonuna ait nörometabolik teorilere göre uyku, uyanıklığın nöral ve metabolik masraflarının geri ödendiği bir dönemdir. 4 bölümden oluşan yavaş dalga uykusu; yavaş nefes alıp verme, düșük kalp hızı, düșük serebral kan akımı ve büyüme hormon salgısında büyük miktarda artış ile fizyolojik yenilenmeye izin verir (59).

Hem yavaş dalga uykusu hem de hızlı göz hareketlerinin olduğu uyku döneminin birlikte hafıza ve öğrenmeyi olumlu etkilediği ileri sürülmüştür (47).

Akșam saatlerindeki maçlarda, profesyonel futbolcular emosyonel strese ek olarak yüksek fiziksel ve mental yüke de maruz kalırlar. Oyuncular psikomotor canlılık ve uyanıklığın azalmaya başladığı saatlerde performans göstermek zorundadır. Düzensiz uyku-uyanıklık dönemleri uykunun sirkadyen ve homeostatik düzenlenmesini, bu durum da uyku kalitesi ve miktarını etkiler. Maç sonrası rutinler (tıbbi bakım, toparlanma yöntemleri, yemek, dönüş yolculuğu vb.) sıklıkla geç yatmaya yol açar, böylelikle uyku kalitesi ve miktarı etkilenir.

Maç sonrası uyku bozukluğunun bir başka olası nedeni ise gelişen sıvı açığını kapatmak amacıyla yüklü miktarda sıvı alımı nedeniyle gece birkaç kez tuvalete gitmek zorunda kalınmasıdır. Sonuçta, maç sonrası birçok oyuncu uyku bozukluğu ile karşılaşır ve bu durum bazı olumsuz sonuçlar doğurur. Uzamış uykusuzluk (30 saatin üzerinde uyku açığı) kas glikojen içeriğinde azalma ile ilişkilidir ve kronik uykusuzluk (12 günün üzerinde devam eden) ağrıların daha fazla şiddetlenmesine yol açabilir (60). Ayrıca, uyku yoksunluğunun yeni deneyimlerin hafizada yer etmesinde zorluklar yarattı̆̆ düşünülmektedir (62).

Uyku ve bağışıklık sistemi arasında yakın bir ilişki vardır. 1 hafta boyunca 7 saatten az uyuyan kişilerde rhinovirus infeksiyonlarının, yani soğuk algınlığının 8 saat ve üzerinde uyuyanlara göre daha fazla görüldügü gösterilmiştir (63). Kısmi uyku yoksunluğu (gece 11:00'den sabah 3:00'e kadar uyanıklı) monoklonal proinflamatuvar sitokin cevabında ve proinflamatuar sitokin gen ekspresyonunda değişiklikler meydana getirmektedir (64). Uykusuz bir gece kesintisiz uyku sonrası ile kıyaslandığında, inflamatuar cevaplarda artış saptanmıștır. Futbolcular uykusuzluk ile hastalık bağlantısı hakkında bilgilendirilmelidir.

Uykusuz geçirilen bir gece sonrası alınacak önlemlerle sonraki gece uykuları düzenlenmelidir. Kas glikojen depolarını yenilemek için yüksek karbonhidrat alımı uyku üzerine olumlu etki yapar. Yüksek karbonhidratlı öğünün uykuya dalma süresini, düşük karbonhidratlı diyete göre belirgin olarak kısalttığ uyku saatinden 4 saat önce alınması gerektiği (1 saat öncesiyle kıyaslandığında) belirtilmiştir (65).

Uykuya geçiş termofizyolojik bir kaskadla bağlantılı olup, vücut ısısının kaybı uykuya dalmayı kolaylaştırmaktadır. Bir toparlanma stratejisi olarak soğuk su uygulaması da vücut ısısını düşürerek (57) uykuyu kolaylaştırır. Karanlık ve sessiz bir ortam, dinlendirici bir müzik dinlemek de önerilmektedir. Maç öncesi performansı arttırma gerekçesiyle kahve tüketimi, maç sonucunu kutlamak için alkol tüketimi ve hiperhidrasyon ise uykusuzluğa neden olabilir.

Bununla birlikte, uykusuz geçen bir gecenin olumsuz etkisi kısa bir öğle uykusuyla giderile- 
bilir. 30 dakikalık bir toparlanma uykusunun, uyanıklık düzeyi ve buna bağlı fiziksel-mental performansı iyileştireceği üzerinde durulmaktadır (66). Kısa süreli uykuya adaptasyon, özellikle yoğun maç takviminin olduğu dönemlerde, futbolcuların geliştirmesi gereken bir alışkanlık olarak görülmektedir.

Tam olarak toparlanma için yeterli olmamakla birlikte, sınırlı bir uykunun ardından ertesi gece 8 saatlik bir uykunun bilișsel performans ve uyanıklığı belirgin olarak düzelttiği belirtilmiştir (61). Takımın tamamı için dinlenme ve uykuuyanıklık periyotları iyi düzenlenmeli, gerekirse bireysel düzenlemeler de yapılmalıdır.

\section{iv) Aktif toparlanma}

Aktif toparlanma soğuma olarak tanımlanabilir ve futbol takımlarında maçın hemen sonrasında ve sonraki günlerde yaygın olarak kullanılmaktadır. Düşük yoğunluklu 15-30 dakikalık koşu, bisiklet ve yüzme aktivitelerini içerir.

Maksimal oksijen tüketiminin \%30-60'ı sdüzeyinde en az 15 dakika yapılan aktivitenin, kandan laktatı uzaklaştırmak veya $\mathrm{pH}$ seviyesini normale çıkarmak için pasif toparlanmaya göre daha etkin olduğu görülmüștür (67). Ancak, laktat düzeyleri, toparlanmanın kalitesini belirleyici bir unsur değildir. Hızlı laktat uzaklaştırılması, daha iyi bir performans anlamına gelmez. Andersson ve ark.'nın elit kadın futbol oyuncularında yaptığı çalışmada, submaksimal düzeyde bisiklet ile aktif toparlanma sonuçlarına göre; gerek fiziksel performans belirteçleri (CM), $20 \mathrm{~m}$ sprint, maximal diz fleksiyonekstansiyon), algınan kas ağrısı ve biyokimyasal belirteçler (CK, üre, ürik asit) açısından gerekse pro ve anti inflamatuvar sitokin cevapları açısından pasif toparlanma arasında fark bulunamamıștır (68).

Aktif toparlanmanın toparlanma stratejilerinde yeri olup olmadığı, varsa egzersiz tipi, süresi, yoğunluğu ile ilgili konularda daha fazla çalışmaya ihtiyaç vardır.

\section{v) Esneklik}

Elit futbol oyuncuları, antrenman ve maç hazırlığı yaparken azımsanmayacak ölçüde esneklik çalışması yapmaktadırlar. Dadebo ve ark.
(69) İngiliz prömiyer liginde kulüplerin toplam antrenman zamanının neredeyse \%40'lık bölümünü esneklik çalışmalarına ayırdıklarını ve bunun da sıklıkla statik esneklik çalışmaları olduğunu raporlamışlardır. Fransız futbol takımlarının \%50'si toparlanma stratejisi olarak esneklik çalışmaları yapmaktadır (47).

Herbert ve ark.'nın metaanalizinde egzersiz ardından esneklik çalışmalarının kas ağrılarını azaltmada klinik olarak başarı sağlamadığı, eksantrik egzersiz sonrası esneklik çalışmalarının ise toparlanma sürecini olumsuz etkileyebileceği gösterilmiştir (70). Lund ve ark. (71) ise hem esneklik hem de eksantrik çalışmaların, geç başlangıçlı kas ağrısına (DOMS) yol açabileceğini, iyi antrene olmayan kişilerde kuadriseps eksantrik ve eksantrik+esneklik egzersiz uygulamasını kıyaslayarak göstermiștir. Buradan anlaşılacağı üzere esnekliğin futbolda toparlanmaya olumlu etkilerine yönelik daha fazla kanıt gerekmektedir.

\section{vi) Basınç giysileri}

Basınç giysileri, son dönemde futbolcular arasında popüler olup, antrenman ve maç sonrası toparlanmayı desteklemek için kullanılmaktadır. Ancak, bu konuda yeterli kanıt olmadığı görülmektedir (46). Plasebo etkisi üzerinde de durulmaktadır. Ancak profesyonel futbolcuların tersine, ileri yaşlardaki sporcular ve spor yapmayan kişilerde bazı fiziksel toparlanma testlerinde olumlu etkilerden bahsedilmiștir. Ayrıca, Gill ve ark. (72), elit rugby oyuncularında maç sonrası 12 saat giyilen tüm bacak basınç giysisinin CK klirensini, pasif toparlanmaya göre daha fazla arttırdığı fakat toparlanma ve fiziksel performans üzerine etkisi olmadığını göstermiştir. Bu giysilerle ilgili bir problem de uygulanacak basıncı ayarlayıp sabit bir şekilde tutmanın zorluğudur. Ancak, normal bir egzersizde veriler yetersiz olmakla birlikte, aşırı eksantrik kas çalışması sonrası gelişen bozulmuş kas mimarisi ve şişlik üzerine etkinliği görünür hale gelmektedir (73).

Basınç giysilerinin, kas ağrısı ve şişmenin alevlenmiş olduğu dönemlerde elit futbolcular için destek olarak kullanılmasının uygun olabileceği düşünülmekle birlikte, bu giysilerin hidroterapi, 
masaj ve aktif toparlanma ile birlikte kullanımının ek bir olumlu etkisi gösterilememiștir (47).

Basınç giysileri, uçak yolculuğunda, özellikle de uzun sürecek yolculuklarda, derin ven trombozu riskini azaltmak amacıyla kullanılabilir. Ancak, gece kullanımlarının rahatsızlık yaratıp vücut ısısını arttırarak uyku kalitesini bozabileceği göz önüne alınmalıdır.

\section{vii) Masaj}

Futbol maçı sonrası toparlanmayı desteklemek için farklı masaj türleri yaygın olarak kullanılmaktadır. Masajının fizyolojik ve psikolojik fonksiyonlar üzerine etkili olabileceği öne sürülmektedir.

Doppler ultrasonografi kullanılarak farklı masaj (öfloraj, petrisaj, tapotman) uygulamaları sonrası kas kan akımları değerlendirilmiş, hem küçük (kol) hem de büyük (kuadriseps) kas gruplarındaki kan akımında değişim saptanamamıştır (74). Kandan laktat ve hidrojen iyonu uzaklaştırılması ve nötrofil sayısı açısından da değişim saptanamamıştır (75). Şu ana kadar yapılan çalışmalar fizyolojik olumlu etkileri gösterememiş olsa da psikolojik etkileri daha belirgindir. Weinberg ve ark. duygu durumu ile masaj arasında pozitif bir ilişki gözlemlemişlerdir (76).

Hilbert ve ark., kas hasarı olan sporcuların hamstring eksantrik pik tork geri kazanımları, tedavi etkinliği ve iyileşme süreci açısından fark olmamasına rağmen, masaj yapılan grupta kas ağrısının belirgin olarak azaldığını rapor etmişlerdir (77). Bu sonuç, egzersiz sonrası kas hasarlarında kas fonksiyonları ile ağrı arasındaki bağlantının zayıf olduğunu da göstermektedir.

Egzersiz sonrası ortaya çıkan kas hasarlarında, egzersizin hemen arkasindan masaj uygulamasının ileri kas hasarına yol açabileceği akılda tutulmalıdır. Viitasalo ve ark. (78), elit sporcularda kuvvet antrenmanları sonrası su masajı uygulandığında, CK ve miyoglobin düzeylerinin daha yüksek seyrettiğini gözlemlemiştir.

Özetle, farklı masaj tiplerinin [öfloraj (sıvazlama), petrisaj (yoğurma), tapotman (darbeleme, perküsyon), friksiyon ve vibrasyon] ha- sarlı kas dokusu, kas fonksiyonu ve performans üzerine etkileri net değildir. Masaj teknikleri arasındaki farklılıklar, uygulayıcıların deneyim düzeyi de bu duruma neden olan faktörler arasında sayılabilir.

\section{viii) Elektrik stimülasyon}

Elektrik stimülasyon, yüzeyel elektrotlar yardımıyla motor nöronların periferik olarak uyarılması ve kas kasılmasını sağlama prensibine dayanır. Birçok elektrik stimülasyon yöntemi bulunmaktadır, ancak toparlanma amacıyla en sık kullanılanlar transkütanöz elektriksel sinir stimülasyonu ve düșük frekanslı elektrik stimülasyonudur. Her iki yöntemin de toparlanma üzerine yararları tartışmalıdır (79).

Düşük frekanslı elektrik stimülasyonun CK ve laktat klirensi üzerine olumlu etkileri bulunmuş olsa da daha önce ifade edildiği gibi, bu biyokimyasal belirteçlerin toparlanmaya etkileri sinırlıdır (47). Elektrik stimülasyonun anaerobik performans üzerine etkisi bulunamamış olmakla birlikte, kas ağrısı yönünden su içi egzersiz ve pasif toparlanmaya göre daha etkin olduğu gösterilmiştir (80).

Sonuç olarak, toparlanma aşamasında sık kullanılmasına rağmen, fiziksel performans üzerine olumlu etkisi açısında bilimsel kanıtlar yetersizdir. Kas ağrısı gibi subjektif belirteçler ise sınırlı kullanıma sahiptir.

\section{SONUÇ}

- Futbolda yorgunluk birçok faktöre bağlıdır. Dehidratasyon, glikojen yoksunluğu, kas hasarı, mental yorgunluk bunlar içinde en iyi bilinen faktörlerdir.

- Profesyonel futbol kulüplerinde yorgunluğu gidermeyi hedefleyen çeşitli toparlanma stratejileri uygulanmaktadır.

- Bazı stratejiler (hidrasyon, diyet, uyku, soğuk su) daha etkin iken, diğerleri tartışmalıdır.

- Hafif sıvı kayıplarının (yaklaşık \%2) giderilmesi için, sıvı kaybının \%150-200'ü oranında yüksek sodyum içeren (61 $\mathrm{mmol} / \mathrm{L}$ ) bir içecek tüketilmesi yeterli kabul edilmektedir. 
- Maç ya da antrenman sonunda alınan protein (süt), kas fonksiyonlarını iyileștirme ve kas ağrılarını azaltmada yardımcıdır.

- Depoları yenilemek ve kas onarımını optimize etmek için, aktivite sonrası 1 saat içinde yüksek karbonhidrat ve protein içeren bir ögün alınması uygundur.

- Kas gücü kayıpları ve kas ağrılarını azaltmak için, omega-3 yağ asitleri ve antioksidanlar günlük diyete eklenmelidir.

- Uyku toparlanma sürecinin önemli bir parçasıdır. Maç sonrası uykusuzlukla sık karşılaşılır. Yeterli uyku, kas ağrıları ve mental yorgunluğu yenmek için gereklidir.

- Kas hasarına yönelik $9-10^{\circ} \mathrm{C}^{\prime}$ de $10-20$ dakikalık soğuk su uygulamaları, maç programının sıkışık olduğu dönemlerde akut inflamasyonu azaltmada etkindir.

- Aktif toparlanma, esneklik, basınç giysileri, masaj ve elektrik stimülasyonun etkinliklerine yönelik henüz yeterince kanıt yoktur.

- Yorgunluğun santral faktörlerinin incelenmesi ve bunlara bağlı toparlanma stratejilerinin geliştirilmesi için yeni çalışmalara ihtiyaç vardır.

\section{REFERENCES}

1. Allen DG, Lamb GD, Westerblad H. Skeletal muscle fatigue: cellular mechanisms. Physiol Rev. 2008;88(1):287-332.

2. Andersson HM, Raastad T, Nilsson $J$, et al. Neuromuscular fatigue and recovery in elite female soccer: effects of active recovery. Med Sci Sports Exerc. 2008;40(2):372-80.

3. Ispirlidis I, Fatouros IG, Jamurtas AZ, et al. Timecourse of changes in inflammatory and performance responses following a soccer game. Clin J Sport Med. 2008;18(5):423-31.

4. Ascensão A, Rebelo A, Oliveira E, et al. Biochemical impact of a soccer match-analysis of oxidative stress and muscle damage markers throughout recovery. Clin Biochem. 2008;41(10-11):841-51.

5. Bigland-Ritchie B, Woods JJ. Changes in muscle contractile properties and neural control during human muscular fatigue. Muscle Nerve. 1984;7(9):6919.

6. Burke LM. Fluid balance during team sports. J Sports Sci. 1997;15(3):287-95.

7. Mohr M, Mujika I, Santisteban J, et al. Examination of fatigue development in elite soccer in a hot environment: a multi-experimental approach. Scand J Med Sci Sports. 2010;20:125-32.

8. Edwards AM, Noakes TD. Dehydration. Sports Med. 2009;39(1):1-3.

9. Hoffman JR, Stavsky H, Folk B. The effect of water restriction on anaerobic power and vertical jumping height in basketball players. Int J Sports Med. 1995;16(04):214-8.

10.Bandelow S, Maughan R, Shirreffs S, et al. The effects of exercise, heat, cooling and rehydration strategies on cognitive function in football players. Scand J Med Sci Sports. 2010;20:148-60.

11.Cian C, Barraud PA, Melin B, et al. Effects of fluid ingestion on cognitive function after heat stress or exercise-induced dehydration. Int J Psychophysiol. 2001;42(3):243-51.

12.Shirreffs SM, Taylor AJ, Leiper JB, et al. Post-exercise rehydration in man: effects of volume consumed and drink sodium content. Med Sci Sports Exerc. 1996;28(10):1260-71.

13.Keller U, Szinnai G, Bilz S, et al. Effects of changes in hydration on protein, glucose and lipid metabolism in man: impact on health. Eur $J$ Clin Nutr. 2003;57(Suppl2):S69-74

14.DiStefano LJ, Casa DJ, Vansumeren MM, et al. Hypohydration and hyperthermia impair neuromuscular control after exercise. Med. Sci. Sports Exerc. 2013;45(6):1166-73.

15.Armstrong LE, Maresh CM, Gabaree CV, et al. Thermal and circulatory responses during exercise: effects of hypohydration, dehydration, and water intake. J Appl Physiol. 1997;82(6):2028-35.

16.Girard 0, Bishop DJ, Racinais S. Hot conditions improve power output during repeated cycling sprints without modifying neuromuscular fatigue characteristics. Eur J Appl Physiol. 2013;113(2):35969.

17.Jacobs I, Westlin N, Karlsson J, et al. Muscle glycogen and diet in elite soccer players. Eur J Appl Physiol. 1982;48(3):297-302.

18.Mohr M, Krustrup P, Bangsbo J. Match performance of high-standard soccer players with special reference to development of fatigue. J Sports Sci. 2003;21(7):51928.

19.Krustrup P, Ørtenblad N, Nielsen J, et al. Maximal voluntary contraction force, SR function and glycogen resynthesis during the first $72 \mathrm{~h}$ after a high-level competitive soccer game. Eur J Appl Physiol. 2011;111(12):2987-95.

20.Byrne C, Twist C, Eston R. Neuromuscular function after exercise-induced muscle damage. Sports Med. 2004;34(1):49-69.

21. Howatson G, Van Someren KA. The prevention and treatment of exercise-induced muscle damage. Sports Med. 2008;38(6):483-503. 
22.Nédélec M, McCall A, Carling C, et al. Recovery in soccer: part I- post match fatigue and time course of recovery. Sports Med. 2012;42(12):997-1015.

23.Lemmink KA, Visscher C. Effect of intermittent exercise on multiple-choice reaction times of soccer players. Percept Mot Skills. 2005;100(1):85-95.

24.Richmond LK, Dawson B, Stewart G, et al. The effect of interstate travel on the sleep patterns and performance of elite Australian Rules footballers. J Sci Med Sport. Journal of science and medicine in sport. 2007;10(4):252-8.

25.Nederhof E, Lemmink KA, Visscher C, et al. Psychomotor speed. Sports Med. 2006;36(10):817-28.

26.Sporis G, Jukic I, Milanovic L, et al. Reliability and factorial validity of agility tests for soccer players. $J$ Strength Cond Res. 2010;24(3):679-86.

27.Rampinini E, Bosio A, Ferraresi I, et al. Match-related fatigue in soccer players. Med Sci Sports Exerc. 2011;43(11):2161-70.

28.Warren GL, Lowe DA, Armstrong RB. Measurement tools used in the study of eccentric contractioninduced injury. Sports Med. 1999;27(1):43-59.

29.Woods C, Hawkins RD, Maltby S, et al. The Football Association Medical Research Programme: an audit of injuries in professional football-analysis of hamstring injuries. Br J Sports Med. 2004;38(1):36-41.

30.Hawkins RD, Hulse MA, Wilkinson C, et al. The association football medical research programme: an audit of injuries in professional football. Br J Sports Med. 2001;35(1):43-7.

31.Kellis E, Katis A, Vrabas IS. Effects of an intermittent exercise fatigue protocol on biomechanics of soccer kick performance. Scand J Med Sci Sports. 2006;16(5):334-44.

32.Lorist MM, Boksem MA, Ridderinkhof KR. Impaired cognitive control and reduced cingulate activity during mental fatigue. Brain Res Cogn Brain Res. 2005;24(2):199-205.

33.Cheung K, Hume PA, Maxwell L. Delayed onset muscle soreness. Sports Med. 2003;33(2):145-64.

34.Coutts AJ, Slattery KM, Wallace LK. Practical tests for monitoring performance, fatigue and recovery in triathletes. J Sci Med Sport. 2007;10(6):372-81.

35.Mougios V. Reference intervals for serum creatine kinase in athletes. Br J Sports Med. 2007;41(10):674-8

36.Tidball JG. Inflammatory processes in muscle injury and repair. Am J Physiol Regul Integr Comp Physiol. 2005;288(2):R345-53.

37.Djaoui L, Haddad M, Chamari K, et al. Monitoring training load and fatigue in soccer players with physiological markers. Physiol Behav. 2017;181:86-94.

38.Singh TK, Guelfi KJ, Landers G, et al. A comparison of muscle damage, soreness and performance following a simulated contact and non-contact team sport activity circuit. J Sci Med Sport. 2011;14(5):441-6.
39.Ekblom B. Assessment of fitness and player profiles. In International football and sports medicine: caring for the soccer athlete worldwide. Proceedings of the International Football and Sports Medicine Conference; 2002 March 22-24, LA, USA. p. 22-4.

40.Maso F, Lac G, Filaire E, et al. Salivary testosterone and cortisol in rugby players: correlation with psychological overtraining items. Br J Sports Med. 2004;38(3):260-3.

41.Kraemer WJ, Spiering BA, Volek JS, et al. Recovery from a national collegiate athletic association division I football game: muscle damage and hormonal status. J Strength Cond Res. 2009;23(1):2-10.

42.Jentjens R, Jeukendrup AE. Determinants of postexercise glycogen synthesis during short-term recovery. Sports Med. 2003;33(2):117-44.

43.Gunnarsson TP, Bendiksen M, Bischoff R, et al. Effect of whey protein-and carbohydrate-enriched diet on glycogen resynthesis during the first $48 \mathrm{~h}$ after a soccer game. Scand J Med Sci Sports. 2013;23(4):50815.

44.Beelen M, Burke LM, Gibala MJ, et al. Nutritional strategies to promote postexercise recovery. Int J Sport Nutr Exerc Metab. 2010;20(6):515-32.

45.Portier H, Chatard JC, Filaire E, et al. Effects of branched-chain amino acids supplementation on physiological and psychological performance during an offshore sailing race. Eur J Appl Physiol. 2008;104(5):787-94.

46.Cockburn E, Hayes PR, French DN, et al. Acute milkbased protein-CHO supplementation attenuates exercise-induced muscle damage. Appl Physiol Nutr Metab. 2008;33(4):775-83.

47.Nédélec M, McCall A, Carling C, et al. Recovery in soccer: part ii- recovery strategies. Sports Med. 2013;43(1):9-22.

48.Ferrucci L, Cherubini A, Bandinelli S, et al. Relationship of plasma polyunsaturated fatty acids to circulating inflammatory markers. J Clin Endocrinol Metab. 2006;91(2):439-46.

49.Tartibian B, Maleki BH, Abbasi A. The effects of ingestion of omega-3 fatty acids on perceived pain and external symptoms of delayed onset muscle soreness in untrained men. Clin J Sport Med. 2009;19(2):115-9.

50.Davis JM, Murphy EA, Carmichael MD, et al. Curcumin effects on inflammation and performance recovery following eccentric exercise-induced muscle damage. Am J Physiol Regul Integr Comp Physiol. 2007;292(6):R2168-73.

51.Wang H, Nair MG, Strasburg GM, et al. Antioxidant and antiinflammatory activities of anthocyanins and their aglycon, cyanidin, from tart cherries. J Nat Prod. 1999;62(2):294-6.

52.Ramaswamy L, Indirani K. Effect of supplementation of tomato juice on the oxidative stress of selected athletes. J Int Soc Sports Nutr. 2011;8(Suppl 1):P21. 
53.Rowsell GJ, Coutts AJ, Reaburn P, et al. Effect of postmatch cold-water immersion on subsequent match running performance in junior soccer players during tournament play. J Sports Sci. 2011;29(1):1-6.

54.Ingram J, Dawson B, Goodman C, et al. Effect of water immersion methods on post-exercise recovery from simulated team sport exercise. J Sci Med Sport. 2009;12(3):417-21.

55.Bailey DM, Erith SJ, Griffin PJ, et al. Influence of coldwater immersion on indices of muscle damage following prolonged intermittent shuttle running. $J$ Sports Sci. 2007;25(11):1163-70.

56.Brophy-Williams N, Landers G, Wallman K. Effect of immediate and delayed cold water immersion after a high intensity exercise session on subsequent run performance. J Sports Sci Med. 2011;10(4):665-70.

57.Vaile J, Halson S, Gill N, et al. Effect of cold water immersion on repeat cycling performance and thermoregulation in the heat. $J$ Sports Sci. 2008;26(5):431-40.

58.Yamane M, Teruya H, Nakano M, et al. Post-exercise leg and forearm flexor muscle cooling in humans attenuates endurance and resistance training effects on muscle performance and on circulatory adaptation. Eur J Appl Physiol. 2006;96(5):572-80.

59.Åkerstedt T, Nilsson PM. Sleep as restitution: an introduction. J Intern Med. 2003;254(1):6-12.

60.Haack M, Mullington JM. Sustained sleep restriction reduces emotional and physical well-being. Pain. 2005;119(1-3):56-64.

61.Sallinen M, Holm A, Hiltunen J, et al. Recovery of cognitive performance from sleep debt: do a short rest pause and a single recovery night help? Chronobiol Int. 2008;25(2):279-96.

62.Walker MP. Cognitive consequences of sleep and sleep loss. Sleep Med. 2008;(Suppl1):S29-34.

63.Cohen S, Doyle WJ, Alper CM, et al. Sleep habits and susceptibility to the common cold. Arch Intern Med. 2009;169(1):62-7.

64.Irwin MR, Wang M, Campomayor CO, et al. Sleep deprivation and activation of morning levels of cellular and genomic markers of inflammation. Arch Intern Med 2006;166(16):1756-62.

65.Afaghi A, O'connor H, Chow CM. High-glycemic-index carbohydrate meals shorten sleep onset. Am J Clin Nutr. 2007;85(2):426-30.

66.Waterhouse J, Atkinson G, Edwards B, et al. The role of a short post-lunch nap in improving cognitive, motor, and sprint performance in participants with partial sleep deprivation. J Sports Sci. 2007;25(14):1557-66.
67.Sairyo K, Iwanaga K, Yoshida N, et al. Effects of active recovery under a decreasing work load following intense muscular exercise on intramuscular energy metabolism. Int J Sports Med. 2003;24(03):179-82.

68.Andersson H, Bøhn SK, Raastad T, et al. Differences in the inflammatory plasma cytokine response following two elite female soccer games separated by a 72 -h recovery. Scand J Med Sci Sports. 2010;20(5):740-7.

69.Dadebo B, White J, George KP. A survey of flexibility training protocols and hamstring strains in professional football clubs in England. Br J Sports Med. 2004;38(4):388-94.

70.Herbert RD, de Noronha M, Kamper SJ. Stretching to prevent or reduce muscle soreness after exercise. Cochrane Database Syst Rev. 2011;(7):CD0045771

71.Lund H, Vestergaard-Poulsen P, Kanstrup IL, et al. The effect of passive stretching on delayed onset muscle soreness, and other detrimental effects following eccentric exercise. Scand J Med Sci Sports. 1998;8(4):216-21.

72.Gill ND, Beaven CM, Cook C. Effectiveness of postmatch recovery strategies in rugby players. $\mathrm{Br} J$ Sports Med. 2006;40(3):260-3.

73.Davies V, Thompson KG, Cooper SM. The effects of compression garments on recovery. J Strength Cond Res. 2009;23(6):1786-94.

74.Tiidus PM, Shoemaker JK. Effleurage massage, muscle blood flow and long-term post-exercise strength recovery. Int J Sports Med. 1995;16(7):478-83.

75.Hemmings B, Smith M, Graydon J, et al. Effects of massage on physiological restoration, perceived recovery, and repeated sports performance. Br J Sports Med. 2000;34(2):109-14.

76.Weinberg R, Jackson A, Kolodny K. The relationship of massage and exercise to mood enhancement. Sport Psychol. 1988;2(3):202-11.

77.Hilbert JE, Sforzo GA, Swensen T. The effects of massage on delayed onset muscle soreness. Br J Sports Med. 2003;37(1):72-5.

78.Viitasalo JT, Niemelä K, Kaappola R, et al. Warm underwater water-jet massage improves recovery from intense physical exercise. Eur J Appl Physiol. 1995;71(5):431-8.

79.Babault N, Cometti C, Maffiuletti NA, et al. Does electrical stimulation enhance post-exercise performance recovery? Eur J Appl Physiol. 2011;111(10):2501-7.

80.Tessitore A, Meeusen R, Cortis C, et al. Effects of different recovery interventions on anaerobic performances following preseason soccer training. $J$ Strength Cond Res. 2007;21(3):745-50. 